\section{Preliminary Critical P-limit Values of 0.01 M CaCl 2 Soil Test Procedure}

\author{
Istvan Jaszberenyi - Jakab Loch \\ University of Debrecen, Centre of Agricultural Sciences, \\ Faculty of Agricultural Sciences, \\ Department of Agricultural Chemistry, Debrecen
}

\section{SUMMARY}

In the last decade, the $0.01 \mathrm{M} \mathrm{CaCl}_{2}$ extraction procedure was tested as a multi-nutrient extractant. In 1995-97, international joint research activities were carried out within the COPERNICUS project. Detailed calibration of conventional and the $0.01 \mathrm{M} \mathrm{CaCl}_{2}$ extraction procedures for $\mathrm{pH}, \mathrm{Mg}$ and $\mathrm{K}$ were published.

The amount of phosphorus extracted using a $0.01 \mathrm{M} \mathrm{CaCl}_{2}$ solution is very low and reflects the intensity parameter of phosphorus bio-availability. As a readily desorbed $P$ fraction of soils can reflect the soil $P$-supply and the $\mathrm{CaCl}_{2}-\mathrm{P}$ values are in close correlation with P-fertiliser rates and P balance. However, the effects of various soil characteristics on $\mathrm{CaCl}_{2}-\mathrm{P}$ values are different and their interpretation is difficult.

Relatively poor correlations were found between amounts of $P$ extracted by conventional and $\mathrm{CaCl}_{2}$ soil test methods and, therefore, $P$ limit values could not be calculated directly. To characterise the soil $P$ supply at different sites, the $\mathrm{CaCl}_{2}$ desorbed $P$ and the adsorbed $P$ in a modified Baker Soil Test were also applied.

Soil test results of Hungarian long-term fertiliser experiments and recommended $\mathrm{CaCl}_{2}-\mathrm{P}$ limit values, calculated on yield effects and soil characteristics, are discussed.

\section{INTRODUCTION}

The authors are engaged in investigating the 0.01 $\mathrm{M} \mathrm{CaCl}_{2}$ soil testing applicability for determination of readily available nutrient and toxic element contents of soils. Some decades ago, this soil testing procedure was recommended for determination single element by Aslyng (1954) for P and Schachtschabel (1954) for Mg. Houba et al. (1986, 1990) proposed this procedure as a multi nutrient soil extractant. This procedure has received attention because of the good relationship between nutrients extracted with $0.01 \mathrm{M} \mathrm{CaCl}_{2}$ and with conventional soil extraction procedures Houba et al. (1986, 1991). The procedure has economical and operational advantages and is, therefore, attractive from a laboratory point of view. The ratios of the easily soluble nutrient elements can be calculated also. In the $0.01 \mathrm{M} \mathrm{CaCl}_{2}$-extracts, the $\mathrm{N}$-fractions and other macro- and micro-nutrients and $\mathrm{pH}$ values can be measured. Experiences with $0.01 \mathrm{M} \mathrm{CaCl}_{2}$ soil test results obtained from long-term field fertiliser experiments are the following:

- a close correlation can be proven between $\mathrm{CaCl}_{2}$ $\mathrm{P}$ quantities and the P-fertiliser rates (Houba et al., 1991) and P-balances (Jaszberenyi et al., 1994);

- there is a rather close correlation among $\mathrm{P}-\mathrm{CaCl}_{2}$, $\mathrm{P}-\mathrm{AL}, \mathrm{P}-\mathrm{CAL}$ and $\mathrm{P}$-water soluble quantities. However, the relationship determined on a specific site, cannot be applied to another because the soluble P-fractions depend on the soil characteristics. (Kücke et al., 1995);

- a reliable correlation can be established between soluble $\mathrm{P}$ values and $\mathrm{P}$ balances, which means that the soil $\mathrm{P}$ reserves, as a result of $\mathrm{P}$ overfertilisation, can be characterised by capacity ( $\mathrm{P}$ $\mathrm{AL}, \mathrm{P}-\mathrm{CAL})$ and intensity parameters $\left(\mathrm{P}-\mathrm{CaCl}_{2}\right.$, P-water) also (Loch et al., 1995).

The applicability of $0.01 \mathrm{M} \mathrm{CaCl}_{2}$ extractant was studied in international joint research activity. Detailed calibration of the conventional and the 0.01 $\mathrm{M} \mathrm{CaCl}_{2}$ extraction procedure for $\mathrm{pH}, \mathrm{Mg}$ and $\mathrm{K}$ were published by Fotyma et al. (1998), Loch et al. (1998) and Baier and Baierova (1998) respectively. This soil testing program was summarised by van Erp et al. (1998).

The introduction of the $\mathrm{CaCl}_{2}$ method to characterise soil P-supply poses difficulties due to a lack of reliable P-limit values. To calculate the $\mathrm{CaCl}_{2}$ $\mathrm{P}$ limit values by conventional methods is almost impossible because of the strong influence of soil characteristics. The site-specific $\mathrm{CaCl}_{2}-\mathrm{P}$ limit values can be related to that $\mathrm{P}$ quantity changed with added soluble $\mathrm{P}$ form in equilibrated soil suspension. The change in $\mathrm{P}$ concentration in equilibrated soil solution makes it possible to estimate the capacity of soils retain added $\mathrm{P}$. The $\mathrm{P}$ fertiliser efficiency is also related to $\mathrm{P}$ adsorption and desorption capacity of soils.

The degree of $\mathrm{P}$ sorption saturation of soils is regarded as an important factor for predicting the risk of soluble $\mathrm{P}$ release into runoff and surface water (Sims, 1998).

\section{MATERIALS AND METHODS}

Calibration soil tests with an $0.01 \mathrm{M} \mathrm{CaCl} 2$ extractant (Houba et al., 1990) were carried out with soil samples from long term field fertilisation trials. On 9 sites 12 NPK treatments were sampled in $28^{\text {th }}$ year of the experiment (Debreczeni, B. and Debreczeni, K., 1994). Soil characteristics of the 9 sites are shown in Table 1.

For determination of adsorbed $\mathrm{P}$ quantities, a modified Baker Soil Test was used (Jaszberenyi et al., 2000). The modified extractant is useful for measuring $\mathrm{Ca}, \mathrm{Mg}, \mathrm{K}$ and $\mathrm{P}$ adsorption and/or desorption. The composition of modified test solution is:

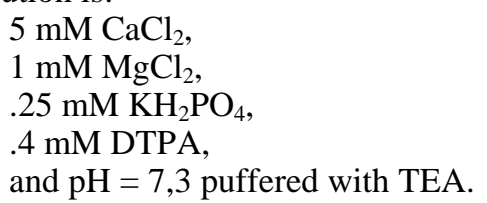


Table 1: Soil properties of the nine sites in the long-term field experiment network (Csatho, 1998)

\begin{tabular}{|c|c|c|c|c|c|c|c|c|c|}
\hline \multirow{2}{*}{ Properties } & \multicolumn{9}{|c|}{ Experimental sites } \\
\hline & NA* & IR & BI & KO & KA & PU & KE & HA & MO \\
\hline Soil type (FAO) & $\begin{array}{c}\text { Calcaric } \\
\text { Phaeosem }\end{array}$ & $\begin{array}{c}\text { Calcaric } \\
\text { Phaeosem }\end{array}$ & $\begin{array}{c}\text { Luvic } \\
\text { Phaeosem }\end{array}$ & $\begin{array}{c}\text { Haplic } \\
\text { Phaeosem }\end{array}$ & $\begin{array}{c}\text { Luvic } \\
\text { Phaeosem }\end{array}$ & $\begin{array}{c}\text { Ochric } \\
\text { Luvisol }\end{array}$ & $\begin{array}{c}\text { Eutric } \\
\text { Cambisol }\end{array}$ & $\begin{array}{c}\text { Luvic } \\
\text { Phaeosem }\end{array}$ & $\begin{array}{l}\text { Calcaric } \\
\text { Fluvisol }\end{array}$ \\
\hline Soil type (USDA) & Mollisol & Mollisol & Mollisol & Mollisol & Mollisol & Alfisol & Alfisol & Vertisol & Vertisol \\
\hline Soil texture & loam & loam & loam & clay loam & clay loam & clay loam & sandy loam & clay & loam \\
\hline Soil OM, \% & 2.7 & 2.4 & 1.9 & 2.6 & 2.7 & 2.0 & 1.7 & 3.5 & 1.7 \\
\hline Soil $\mathrm{pH}_{\mathrm{KCl}}$ & 7.2 & 7.4 & 5.6 & 3.9 & 4.7 & 3.9 & 5.9 & 6.1 & 7.4 \\
\hline $\mathrm{CaCO}_{3}$ & 6.0 & 8.0 & - & - & - & - & traces & traces & 21.0 \\
\hline $\mathrm{y}_{1}, \mathrm{me} / 100 \mathrm{~g}$ & - & - & - & 19 & 24 & 16 & - & - & - \\
\hline$<0.01 \mathrm{~mm}$ particles, \% & 38 & 36 & 45 & 58 & 59 & 49 & 37 & 53 & 35 \\
\hline Clay $\%(<0.002 \mu \mathrm{m})$ & 23 & 24 & 33 & 46 & 45 & 31 & 22 & 36 & 25 \\
\hline \multicolumn{10}{|c|}{ Minerals in clay fraction, \% } \\
\hline Illite & 47 & 50 & 45 & 27 & 56 & 33 & 59 & 29 & 48 \\
\hline Kaolinite & - & - & - & 20 & - & 14 & 10 & - & - \\
\hline Smectite & 16 & 8 & 17 & 37 & 7 & 27 & 6 & 47 & 16 \\
\hline Illite-smectite & 5 & 10 & 10 & 10 & 11 & 19 & 9 & 5 & 7 \\
\hline
\end{tabular}

* Experimental sites: NA: Nagyhörcsök; IR: Iregszemcse; BI: Bicsérd; KO: Kompolt; KA: Karcag; PU: Putnok; KE: Keszthely;

HA: Hajdúböszörmény; MO: Mosonmagyaróvár

Procedure: 5,0 g soil samples were shaken with $50 \mathrm{~cm}^{3}$ modified Baker Test solution for 2 hours. Soil suspension were filtered with MN 640 filter paper. The $\mathrm{P}, \mathrm{K}$ and $\mathrm{Mg}$ concentrations of the initial equilibrant and extracts were measured ICP-AES. Differences between the final and initial concentrations were calculated and expressed as dP, $\mathrm{dK}$ and $\mathrm{dMg} \mathrm{mg} / \mathrm{kg}$ soil. In this paper, the adsorbed $\mathrm{P}$ quantities are discussed in relation to soil $\mathrm{pH}$ and clay content.

\section{RESULTS AND DISCUSSION}

\section{Experiences with the $\mathrm{CaCl}_{2}$ method}

As a result of comparative studies the advantages of $0.01 \mathrm{M} \mathrm{CaCl}_{2}$-soil test method to estimate the soil nutrient supply was proven. The $\mathrm{CaCl}_{2}-\mathrm{P}$ and AL-P quantities have an increasing tendency with fertiliser $\mathrm{P}$ doses. Both methods are useful to detect the cumulated $\mathrm{P}$ fertiliser quantities in soil. The advantage of the $\mathrm{CaCl}_{2}$ method is that the relative change in $\mathrm{CaCl}_{2}-\mathrm{P}$ amount is higher than the relative change in $\mathrm{AL}-\mathrm{P}_{2} \mathrm{O}_{5}$ quantities as an effect of $\mathrm{P}$ fertilisation. This means that the $\mathrm{CaCl}_{2}$ method seems to be rather sensitive to estimate $\mathrm{P}$ over-fertilisation. The relationship between $\mathrm{CaCl}_{2}-\mathrm{P}$ and $\mathrm{AL}-\mathrm{P}_{2} \mathrm{O}_{5}$ can be characterised by exponential function at a number of sites.

\section{Relations between adsorbed $\mathbf{P}$ and $\mathrm{CaCl}_{2}-\mathrm{P}$ content of soils}

The Figure 1 shows the relationship between adsorbed $\mathrm{P}$ percentage and $\mathrm{CaCl}_{2}-\mathrm{P}$ values at different sites.

The adsorption curves have different slopes with different $\mathrm{P}$ adsorption capacities of soils. It can be concluded that the more fertiliser $\mathrm{P}$ enriched in soil, the more $\mathrm{P}$ remains soluble with decreasing $\mathrm{P}$ adsorption and enhanced $P$ fertiliser efficiency.
Figure 1: Adsorbed $\mathbf{P} \%-\mathbf{C a C l}_{2}-\mathbf{P}$

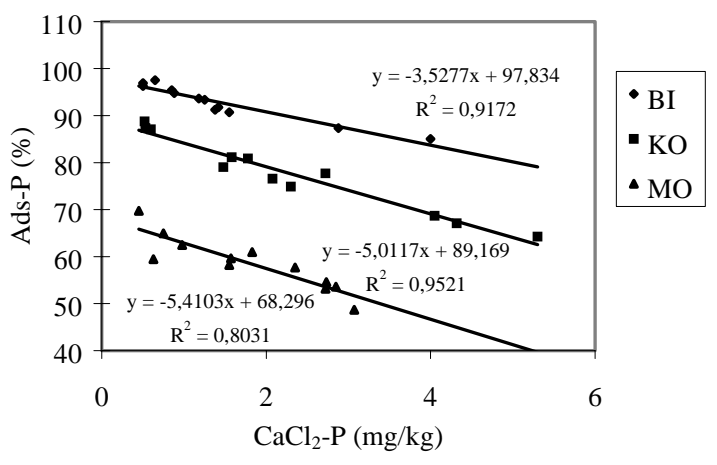

\section{Calculations of $\mathbf{P}$ limit values based on yields}

For estimation of $\mathrm{CaCl}_{2}-\mathrm{P}$ limit values at different sites, the yield effects of $\mathrm{P}$ fertilisation were calculated. The yield differences $\left(\mathrm{Y}_{\max }-\mathrm{Y}\right)$ were related to the soil $\mathrm{CaCl}_{2}-\mathrm{P}$ amounts as follows:

$$
\mathrm{Y}_{\max }-\mathrm{Y}=\mathrm{a}+\mathrm{b}^{*} \ln \mathrm{CaCl}_{2}-\mathrm{P}
$$

The interception point of the regression line on $\mathrm{x}$ axis is the theoretical $\mathrm{CaCl}_{2}-\mathrm{P}$ limit value. Practically the $\mathrm{CaCl}_{2}$-P limit at $90 \%$ of $\mathrm{Y}_{\max }$ can be regarded as acceptable. In a year, the yield effect of Pfertilisation has great uncertainty. Therefore, the $\mathrm{CaCl}_{2}-\mathrm{P}$ contents of soils were related to 20 year yield averages. Trend of yields and the $\mathrm{CaCl}_{2}-\mathrm{P}$ values allow to estimate the limits on different sites. The estimated and calculated $\mathrm{CaCl}_{2}-\mathrm{P}$ limit values stand in good correlation.

\section{The effect of soil characteristics on calculated $\mathrm{CaCl}_{2}$-P limit values}

The $\mathrm{pH}$ values and clay content of soils were related to the P-limits. Because of the few number of sites the regressions have low level of signification. 
However, the relation between regression curves and

the trend of points are good. On soils with strongly acidic and basic $\mathrm{pH}$ values, the $\mathrm{CaCl}_{2}-\mathrm{P}$ limits are higher than on soils with slightly acidic or neutral $\mathrm{pH}$ range (Figure 2). A similarly well-defined trend can be observed as an effect of clay content (Figure 3). 
With increasing soil clay content, the $\mathrm{CaCl}_{2}-\mathrm{P}$ limit values decrease. Based on our experience, the preliminary $\mathrm{CaCl}_{2}-\mathrm{P}$ limit values are recommended

Figure 2: $\mathrm{CaCl}_{2}-\mathrm{P}$ limits and $\mathbf{p H}(\mathrm{KCl}) \mathbf{9 0 \%}$ of $\mathbf{Y i e l d}_{\max }$

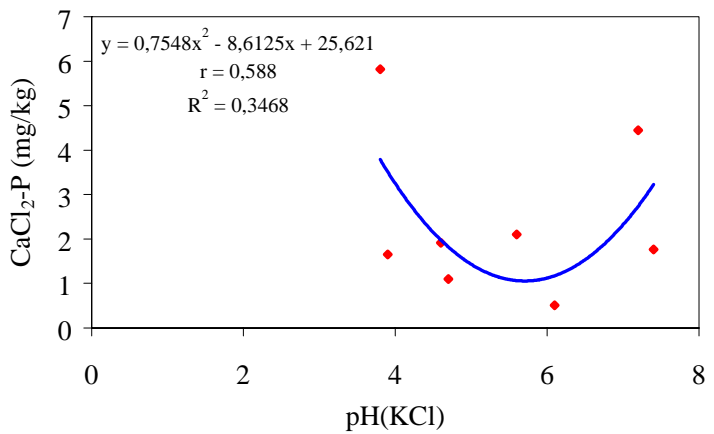

Figure 3: $\mathbf{C a C l}_{2}-\mathbf{P}$ limits - clay content $\mathbf{9 0} \%$ of $\mathbf{Y i e l d}_{\max }$

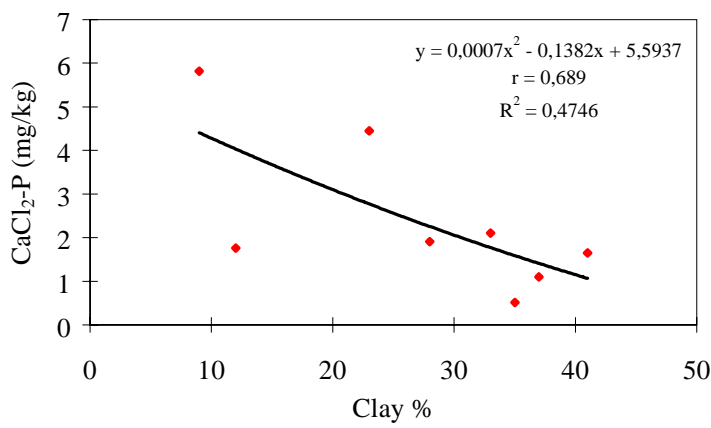

(Table 2). For verification of these $\mathrm{CaCl}_{2}-\mathrm{P}$ limit values, additional results of P-fertiliser yield effects are required.

Table 2: Preliminary P limit values (mg P/kg) (0.01 $\mathrm{M} \mathrm{CaCl}_{2}$ extraction, 1:10 w/v)

\begin{tabular}{|l|r|r|r|}
\hline \multirow{2}{*}{ Soil testure } & \multicolumn{3}{|c|}{$\mathbf{p H - K C l}$} \\
\cline { 2 - 4 } & \multicolumn{1}{|c|}{$<\mathbf{6 , 0}$} & $\mathbf{6 , 0}-\mathbf{7 , 0}$ & \multicolumn{1}{c|}{$>\mathbf{7 , 0}$} \\
\hline Sand & $3,0-5,0$ & $2,0-3,0$ & $3,0-5,0$ \\
\hline Loam & $2,0-3,0$ & $1,0-2,0$ & $2,0-3,0$ \\
\hline Clay & $1,0-2,0$ & $0,5-1,0$ & $1,0-2,0$ \\
\hline
\end{tabular}

\section{ABSTRACT}

Results of comparative studies on soils of Hungarian long-term field fertiliser trials, show that the $0.01 \mathrm{M} \mathrm{CaCl}_{2}$ soluble $\mathrm{P}$ quantities characterise the soil $\mathrm{P}$ supply. $\mathrm{P}$ over-fertilisation can be established by this soil test method. Preliminary $\mathrm{P}$ limit values are recommended based on $\mathrm{P}$ yield effects and soil characteristics. Verification the recommended $\mathrm{P}$ limit values requires additional results of field experiments.

\section{REFERENCES}

Aslyng, H. C. (1954): The lime and phosphate potentials of soils, the solubility and availability of phosphates. Bulletin of the Hydrotechnical laboratory, Copenhagen

Baier, J.-Baierova, V. (1998): One hundredth molar calcium chloride soil extraction procedure. Part IV: Calibration with conventional soil testing methods for potassium. Commun. Soil Sci. Plant Anal., 29. 11-14. 1641-1648.

Csatho, P. (1998): Correlations between two soil extractants and corn leaf potassium contents from Hungarian field trials. Commun. Soil Sci. Plant Anal., 29. 11-14. 2149-2160.

Debreczeni, B.-Debreczeni, K. (1994): Fertilization research, 1960-1990. Akadémiai Kiadó, Budapest, Hungary (in Hungarian)

Erp, P. J. van-Houba, V. J. G.-Beusichem, M. L. van (1998): One hundredth molar calcium chloride soil extraction procedure. Part I. A review of soil chemical analytical and plant nutrition aspects. Commun. Soil Sci. Plant Anal., 29. 11-14. 1603-1623.

Fotyma, M.-Jadczyszyn, T.-Jozefaciuk, G. (1998): One hundredth molar calcium chloride soil extraction procedure. Part II. Calibration with conventional soil testing methods for $\mathrm{pH}$. Commun. Soil Sci. Plant Anal., 29. 11-14. 1625-1632.

Houba, V. J. G.-Jaszberenyi, I.-Loch, J. (1991): Application of $0.01 \mathrm{M} \mathrm{CaCl}_{2}$ as a single extraction solution for evaluation of the nutritional status of Hungarian soils. Debreceni Agrártudományi Egyetem Tud. Közl., XXX. 85-95.

Houba, V. J. G.-Novozamsky, I.-Huybreghts, A. W. M.-Lee, J. J. van der (1986): Comparison of soil extractions by $0.01 \mathrm{M}$ $\mathrm{CaCl}_{2}$, by EUF and by some conventional extraction procedures. Plant and Soil, 96. 433-437.
Houba, V. J. G.-Novozamsky, I.-Lexmond, M. Th.-Lee, J. J. van der (1990): Applicability of $0.01 \mathrm{M} \mathrm{CaCl}_{2}$ as a single extractant for the assessment of the nutrient status of soils and other diagnostic purposes. Commun. Soil Sci. Plant Anal., 21. 2281-2290.

Jaszberenyi, I.-Kovacs, B.-Loch, J. (2000): Experiences with the modified Baker-Amacher soil extraction procedures in Hungary. Commun. in Soil Sci. and Plant Anal., 31. 11-14.

Jaszberenyi, I.-Loch, J. (1996): Soil phosphate adsorption and desorption in $0.01 \mathrm{M}$ calcium chloride electrolyte. Commun. Soil. Sci. Plant Anal., 27. 5-8. 1211-1225.

Jaszberenyi, I.-Loch, J.-Sarkadi, J. (1994): Experiences with 0.01 $\mathrm{M} \mathrm{CaCl}_{2}$ as an extraction reagent for use as a soil testing procedure in Hungary. Commun. Soil Sci. Plant Anal., 25. 910. 1771-1777.

Kücke, M.-Jaszberenyi, I.-Loch, J.-Vago, I. (1995): Beziehungen unterschiedlicher P-Extraktionsverfahren in Abhangigkeit von Standort, P-Düngung und Probenahmezeitpunkt. VDLUFASchriftenreihe, 40. 205-208.

Loch, J.-Jaszberenyi, I. (1995): Untersuchung der Phosphatadsorption und -Desorption in Dauerdüngungsfersuchen. Agribiol. Res., 48. 1. 53-62.

Loch, J.-Jaszberenyi, I.-Kücke, M.-Vago, I. (1995): Beziehungen unterschidlicher P-Extractionsverfahren zur P-Bilanz. VDLUFA Schriftenreihe, 40. 209-212.

Loch, J.-Jaszberenyi, I.-Vago, I. (1998): Hundredth molar calcium chloride extraction procedure. Part III. Calibration with conventional soil testing methods for magnesium. Commun. Soil Sci. Plant Anal., 29. 11-14. 1633-1640. 
Schachtschabel, P. (1954): Das planzenverfügbare Magnesium des Bodens und seine Bestimmung. Z. Pflanzenernähr., Düng. u. Bodenkunde Weinheim/Bergstr. 67. S. 9-23.

Sims, J. T. (1998): Phosphorus soil testing: Innovations for water quality protection. Commun. Soil Sci. Plant Anal., 29. 11-14. 1471-1489. 